\title{
Ageing of Some Painting Materials Subjected to Thermal Treatment in Natural Esters
}

\begin{abstract}
TRAIAN RUS'1, ALINA RUXANA CARAMITU², LIVIA CARMEN UNGUREANU³, VIRGIL MARINESCU², ADRIANA MARIANA BORS4*, DANUT IONEL VAIREANU ${ }^{1}$

1.Politehnica University of Bucharest, Faculty of Applied Chemistry and Materials Science, Department of Inorganic Chemistry, Physical Chemistry and Electrochemistry, 1-7 Polizu Str. , 011061, Bucharest, Romania

2.National Institute for Research and Development in Electrical Engineering INCDIE ICPE-CA, 313 Splaiul Unirii, 030118, Bucharest, Romania

${ }^{3}$ National Institute for Development and Testing in Electrical Engineering-ICMET, 118 A Decebal Blvd., 200746, Craiova, Romania 4.ICPE SA., 313 Splaiul Unirii, 030138, Bucharest, Romania

This paper describes the evaluation of the aging process of some polymeric painting materials subjected to a thermal treatment in electro insulating fluids, based on natural esters (vegetable oils). The paint layers surface morphology was comparatively characterized by FESEM technique, prior to the exposure, and after $1000 \mathrm{~h}$ of exposure to vegetable oil, heated at $130^{\circ} \mathrm{C}$. The results show a substantial increase in the pulling resistances for all the painting materials subjected to this investigation, especially in the presence of the Kraft insulating paper and copper foil (inserted compulsory to emulate the actual working environment), due to an increase in the painting material adhesion, as well as an increase of the tensile strength of the paint layer. These findings may open new theoretical and practical research prospects, particularly in the field of preliminary treatments for materials used for heavy duty industrial transformers.
\end{abstract}

Keywords: paint aging, thermal treatment, natural esters, paint pulling resistance, paint tensile strength

In order to ensure good working and living conditions in a clean and safe environment it is required that manufacturing of the equipment and of the technological systems to be done using materials and technologies which are environmental friendly and, also, to ensure a safe, longterm functioning. All these factors are of a greatimportance and should be considered as a priority [1-3].

It is highly important to reduce the formation of the persistent pollutants during manufacturing of the equipment and technological systems, during the working time of these equipments and during recycling / treatment of the waste material which occurs at the end of their life time. [4-6]. There is of an utmost importance the local and global monitoring of the pollutants which are a consequence of human activity. [7-11]. Further to the technological development, our life fully depends on continuous and safe electrical power supply. Production of electrical power using fossil fuels and/or biomass has a major contribution to the pollution of the environment through emissions of $\mathrm{CO}_{2}$ and of other different pollutants $\left(\mathrm{SO}_{2}, \mathrm{NO}_{x^{\prime}} \text { powders etc. }\right)^{2}$ [9-12].

The trannsport and distribution of electrical power it is done through the electrical networks and electrical plants; the durability and safety of these networks and plants have a major impact upon the continuity of electrical power supply to all consumers, including those which are of a major importance such as hospitals, security systems, etc.

The durability and safety of electrical networks and plants it is closely related with the ageing of the materials used for building them. This ageing occurs further to the interaction of these materials with their working environmentand, also, as a consequence of the interaction betw een different materials. Thus, the degradation of the paint coatings applied on metallic parts (under the direct action of the different environment factors [13-17] including the microbiological factors [18-32]) leads to corrosion of these metallic parts - in some extreme cases, to the irreversible damage of the steel electrical pillars [33] or of the reinforced concrete electrical pillars [34-37].

A particular case, which is relatively less studied until now, is the case of the interaction between the polymeric painting systems and the electro insulating fluids inside of the electrical transformers tanks, under the thermal, electrical and chemical stress [38, 39].

Inside of the electrical transformers tanks, the painting materials are exposed to the thermal ageing through the thermo-oxidative processes with the participation of the oxygen which is dissolved in the electro insulating fluid (transformer oil) [38] and further to the interaction with the transformer oil [38, 39]. Under these circumstances, can be observed, on one side, the degradation of the coating (which may lead to the exfoliation of the coating and to the failure of the combined insulation system oil / Kraft insulation paper of the transformer itself) and, on the other side, to the degradation of the transformer oil and of the electro insulating paper.

It should be underlined that, further to the thermooxidative ageing of the oil transformers [40-46] and the degradation of the electro insulating paper, highly determined by the dissolved oxygen and the humidity of the oil transformer, several toxic furfural products [47-50] and / or of flammable gases are produced [51-58] which may lead to the explosion of the oil transformer followed by devastating wildfires $[55,57]$.

During the thermo-oxidation processes, the polymeric painting materials used for the internal painting of the transformers' tanks consume the oxygen dissolved in the transformer oil. In this way, the amount of the oxygen available for the thermo-oxidation processes of the insulating fluid and of the insulating paper is reduced, which leads to an increased stability of these materials respectively to a diminished formation of furfurals and gases $[48,57]$.

\footnotetext{
*email: adrianambors@gmail.com; Phone: 0773917319
} 
These experimental findings [48] may be favorable to the complex materials system (electro insulating oil / painting materials / electro insulating paper/copper) which are in direct contact inside of the transformer's tank - of course, assuming that the integrity and the adhesion of the painting system is not affected.

Under the above mentioned circumstances, the scope of work is to assess the adhesion of several coatings applied on mild steel (commonly used for manufacturing of the transformer tanks) exposed to thermal ageing being immersed in an electro insulating fluid based on natural esters (vegetal oils).

\section{Experimental part \\ Working procedure}

In order to assess the consequences of the thermal ageing of some polymeric painting materials through thermal treatment and immersion in an electro insulating fluid based on natural esters (vegetal oils) several samples were used made of low alloyed steel S235) 2G3 and painted by immersion in three different types of painting materials (PM-1, PM-2 and PM-3) as shown in table 1.

After the full curing of the paint in the air ( 10 days at 23 $\pm 3{ }^{\circ} \mathrm{C}, \mathrm{RH} 70 \pm 10$ ), the dry film thicknesses (DFT) of each layer were measured using a DeFelsko Positector 6000 gauge.

Batches of three samples were immersed in transformer oil, in closed vessels (limited access of the atmospheric oxygen); in order to simulate the conditions inside the transformer tank, the following samples were used: 300 $\mathrm{mL}$ of transformer oil and, respectively, $300 \mathrm{~mL}$ of transformer oil together with $100 \mathrm{~cm}^{2} \mathrm{~K}$ raft insulating paper (type 22 HCC, made by Weidmann) and $100 \mathrm{~cm}^{2}$ of copper sheet for electrical use [62]. The samples were exposed to a thermal treatment of $130 \pm 3^{\circ} \mathrm{C}$ for $1000 \mathrm{~h}$ in a thermostat type XL 98 - France Etuve.

As an electro insulating oil, vegetal oil having a high oleic content was used [63].

The adhesion of coating was measured on reference samples and on the samples exposed to the thermal treatment as well by using a Positest AT- an automatic adhesion tester made by DeFelsko.

The paint layers surface morphology (both initially and after 1000 hours exposure to oil at $130^{\circ} \mathrm{C}$ ), was analyzed by SEM microscopy using Auriga (Zeiss) field emission scanning electron microscope (FESEM).

\section{Results and discussions}

The averages results (calculated as an average of three readings) of DFT and pull-off test, are shown in table 2.

Analyzing the data presented in table 2 , we observe that the thermal treatment leads to increased values of the pulloff test for all three paint material samples; the higher values corresponds to simultaneous exposure of the paint to the copper foil land Kraft insulating paper.

In case of PM-1 - the initial samples (which were not exposed to thermal ageing), the pull-off test values are $2.78 \mathrm{MPa}$ at $60 \%$ adhesion failure between the substrate and paint and at $30 \%$ adhesion failure between the paint and adhesive. Further to the ageing for 1000 hours at 130 ${ }^{\circ} \mathrm{C}$ in vegetal oil [62], the pull-off test values increases at
$2.95 \%$ (cca. $6 \%$ ) - the main characteristic is the cohesion of the paint material PM-1.

With regards to the exposure under similar conditions plus copper foil and Kraft insulating paper, we noticed a substantial increase of the pull-off test values at $5.63 \mathrm{MPa}$, respectively almost twice the reference value. This behavior indicates the fact that the complex thermal interaction processes between the vegetal oil and the painting material [62] (which leads to an increase of the paint's cohesion of PM-1) are enhanced by the presence of the copper foil and of the Kraft insulating paper.

In case of PM-2, further to thermal exposure and immersion in transformer oil, the pull-off test results show an increase from 3.49 MPa to 3.88 MPa (cca. $11 \%$ increase) and, in presence of copper foil and of the insulating paper, at $4.4 \mathrm{MPa}$ (cca. $26 \%$ increase) - all failures are cohesive failures of PM-2 (which is the main influence).

In case of PM-3, further to thermal exposure and immersion in transformer oil, the pull-off test results shows an increase from $3.28 \mathrm{MPa}$ to $5.23 \mathrm{MPa}$ (cca. $60 \%$ increase)-the failures are, mainly, adhesion failures between steel substrate and painting material.

The comparative analysis of the data presented in table 2 , shows that the cohesion of the paint material increases further to the thermal treatment, the most significant changes can be observed for the samples which were simultaneously exposed to thermal oil, copper foil and Kraft insulating paper. It can be, also, observed that, up to cca. 5 $M P a$, the predominant failures are cohesive failures of the coating and, in case of values higher than $5 \mathrm{MPa}$, the predominant failures are adhesion failures between the paint and steel substrate.

The typical SEM images of the investigated paint samples which were exposed to different treatments are comparatively shown in figures 1-3.

Comparing images a), b) and c) of figure 1 , one can see that, further to the thermal treatment, the morphology of the surface of the PM-1 samples it is significantly changed which suggests that the painting material underwent structural changes - these changes explaining the evolution of the pull-off test values.

As far as images a), b) and c) of figure 2 are concerned, it can be seen that, further to the thermal treatment, the morphology of the surface of the $\mathbf{P M - 2}$ samples is not significantly changed, which may be an explanation for the relatively small changes of the pull-off test values as shown in table 2.

The comparative analysis of images a) of figures 1-3, shows that the three samples do not have major differences from the microstructure point of view.

As for images a), b) and c) of figure 3, one may notice that, further to the thermal treatment, the morphology of the surface of the PM-3 samples is significantly changed, which suggests that the painting material underwent structural/ composition changes - these changes may explain the evolution of the pull-off test values shown in Table 2 and, respectively, the chemical behavior of PM-3 (which is different from PM-1 and PM-2 samples) by formation of gases and furanic compounds [38] and, also, the evolution of $\mathbf{p H}$ (acidity) and humidity [39] of the investigated oil under thermal stress working conditions.

\begin{tabular}{|c|l|l|c|}
\hline $\begin{array}{c}\text { Material } \\
\text { code }\end{array}$ & \multicolumn{1}{|c|}{ Painting material } & Composition & Solvent \\
\hline PM-1 & AquaCover 200 [59] & Bi-component, polyamine cured epoxy primer & tap water \\
\hline PM-2 & Sigmaprime 200 [60] & Bi-component, pure epoxy primer & Thinner 91-92 \\
\hline PM-3 & Phenguard 930 $[61]$ & Bi-component, epoxy-novolac primer & Thinner 91-92 \\
\hline
\end{tabular}

Table 1

PAINTING MATERIALS 


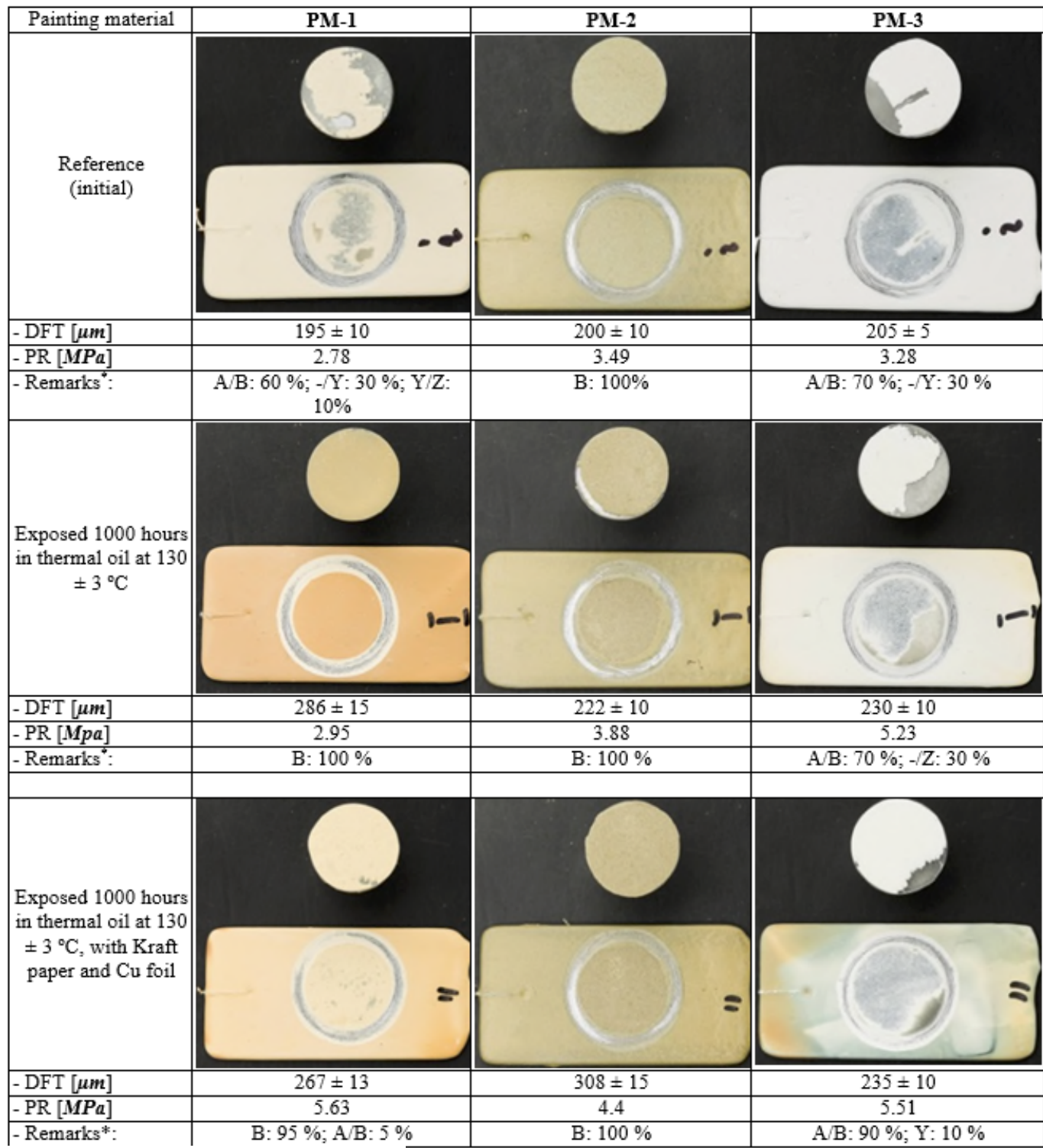

Table 2

DFT AND PULL-OFF TEST

VALUES OF THE

INVESTIGATED COATING

SAMPLES

${ }^{*}$ As per [63]: A/B: adhesion failure between the 1st coat and substrate;

$B$ : cohesion failure of the 1st coat; -/Y: adhesion failure between the paint and the adhesive;

$Y$ : cohesive failure of the adhesive; Y/Z: adhesion failure between the adhesive and dolly.
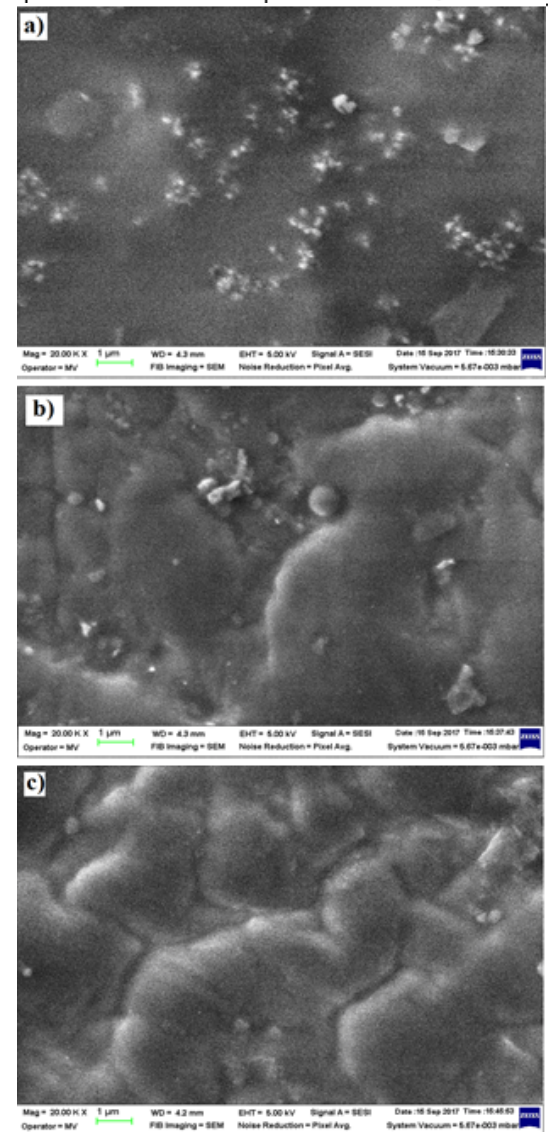

Fig. 1. SEM images of

PM-1 samples: a) initial / reference; b) exposed 1000 hours in thermal oil at $130 \pm 3^{\circ} \mathrm{C} ; \mathrm{C}$ ) exposed 1000 hours in thermal oil at $130 \pm 3^{\circ} \mathrm{C}$ with Kraft paper and $\mathrm{Cu}$ foil
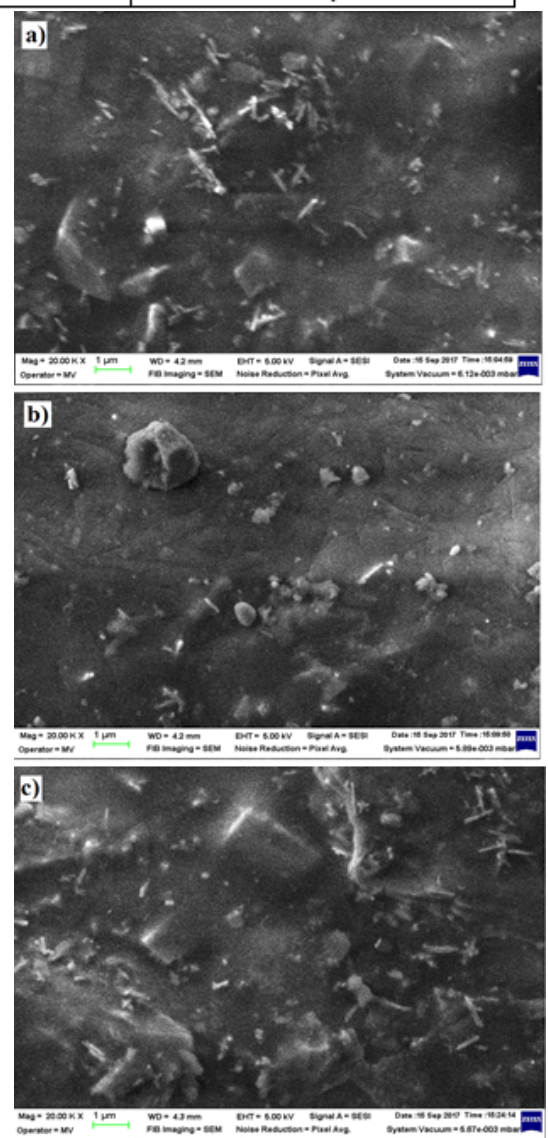

Fig. 2. SEM images of PM-2 samples:

a) initial / reference; b) exposed 1000 hours in thermal oil at $130 \pm 3{ }^{\circ} \mathrm{C}$;

c) exposed $1000 \mathrm{~h}$ in

thermal oil at

$130 \pm 3^{\circ} \mathrm{C}$ with Kraft paper and $\mathrm{Cu}$ foil 

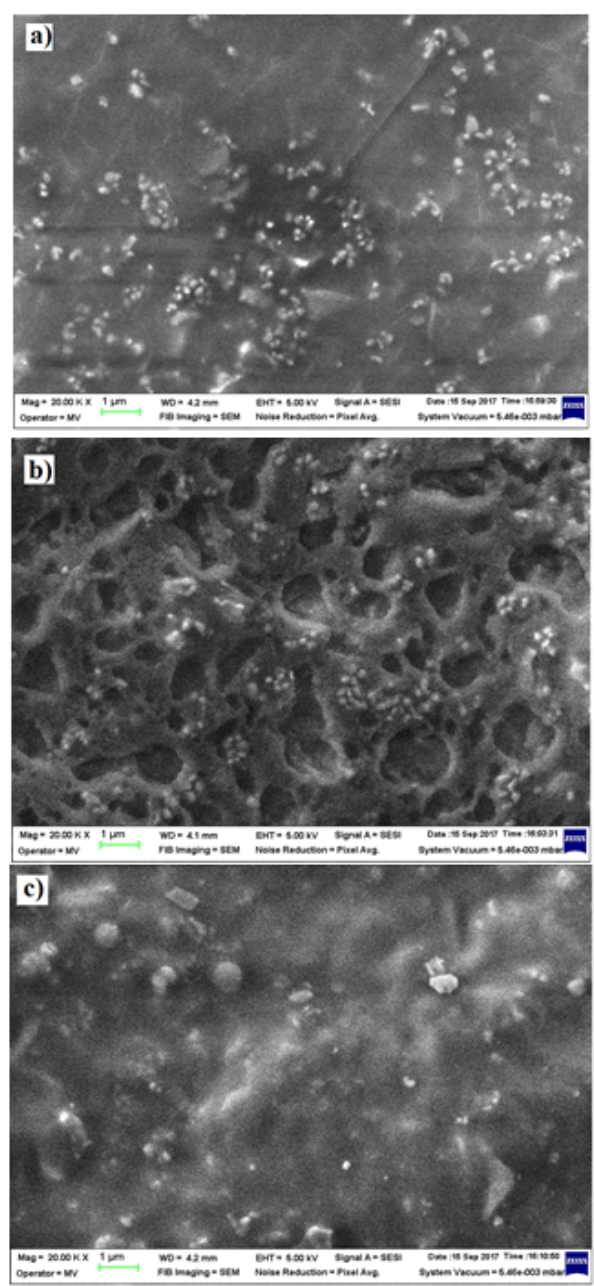

Fig. 3. SEM images of PM-3 samples: a) initial/ reference; $b$ ) exposed $1000 \mathrm{~h}$ in thermal oil at $130 \pm 3^{\circ} \mathrm{C}$; C) exposed 1000 hours in thermal oil at $130 \pm 3^{\circ} \mathrm{C}$ with Kraft paper and $\mathrm{Cu}$ foil

\section{Conclusions}

The modifications of the thermal aging induced process, conducted over $1000 \mathrm{~h}$, at $130 \pm 3^{\circ} \mathrm{C}$, in natural insulating fluid (vegetable oil), in the absence and in the presence of copper foil and Kraft insulating paper (to simulate transformer operating conditions) were assessed by determining the pulling resistance, as well as by SEM technique, for three different types of painting materials. The results obtained by data processing showed that the pulling resistance of the investigated materials increases after the applied thermal treatments, the increases being more substantial in the presence of copper foil and Kraft insulation paper.

The pulling resistance increases in the case of the samples subjected to the thermal treatment are the result of an increase in the adhesion of the painting material applied to the steel plate support, as well as an increase in the tensile strength of the paint layer. These findings are also supported by the results of the SEM analysis, which clearly indicated the surface morphology changes, suggesting that the painting materials have been structurally changed.

Acknowledgment: This work was financially supported by the UEFISCDI of Romania, under the scientific Programme PN II -PCCA, Contract 100/2014-UPMEE and Programme NUCLEU 2016-2017", contract PN 16110211 /2016. Mr. Traian Rus had his tuition fees financially supported by the Ministry of National Education of Romania.

\section{References}

1.STERE, E.A., POPA, I., Electrotehnica, Electronica, Automatica (EEA), 65 (1), 2017, pp. 97-102.

2.STERE E.A., POPA I., Electrotehnica, Electronica, Automatica (EEA), 65 (2), 2017, pp. 163-170.

3.STERE E.A., POPA I., Electrotehnica, Electronica, Automatica (EEA), 65 (3), 2017, pp. 213-220.

4. NEAMTU, S., BORS, A.M., STEFAN, S., Rev. Chim. (Bucharest), 58 no. 9, 2007, pp. 938.

5. BORS, A.M., MEGHEA, A., NEAMTU, S., LESNIC, M., Rev. Chim. (Bucharest), 58, no. 8, 2007, p. 776

6.BORS, A.-M., MEGHEA I., NICOLESCU A.-M., BORS A.-G., 12h International Multidisciplinary Scientific Geoconference (SGEM), 2012, Albena, Bulgaria, V, p. 891.

7.SZEP, R., KERESZTES, R., KORODI, A., TONK, S., CRACIUN, M.E., Rev. Chim. (Bucharest), 68, no. 8,2017, p. 1763

8.BORS, A-M., CIUCULESCU, C.A., MEGHEA, A., Rev. Chim. (Bucharest), 58, no. 2, 2007, p. 151

9.LINGVAY, I., BORS, A-M., LINGVAY, D., Electric Vehicles International Conference (EV), 2017, IEEE Xplore 2017, DOI: 10.1109/ EV.2017.8242108 pp. 1-5

10.BORS, A.M., BALACEANU, C.M., LINGVAY, I., Electric Vehicles International Conference (EV), 2017, IEEE Xplore, DOI: 10.1109/ EV.2017.8242107, pp. 1-5

11.SCHAUER, J., KLEEMAN, J., CASSR, R.T., Environ. Sci. Technol., 35 (9), 200, pp. 1716-1728.

12. LINGVAY, I., BORS, A.-M., LINGVAY, D., BALACEANU, C.M., SZATMARI, I., MATEI, A.T., Electrotehnica, Electronica, Automatica (EEA), 65 (4), 2017, pp. 5-11

13.RUS, T., CARAMITU, A., MITREA, S., LINGVAY, I., Diagnostic of Electrical Machines and Insulating Systems in Electrical Engineering (DEMISEE), 2016, IEEE Xplore, DOI: 10.1109/DEMISEE.2016.7530466, pp. 60-65

14.ZUBIELEWICZM., KROLIKOWSKA A., Progress in Organic Coatings, 66, 2009, pp. 129-136.

15.HU, J., LI, X., GAO, J., ZHAO, Q., Progress in Organic Coatings, 65, 2009, pp. 504-509.

16.RUS, T., LINGVAY, I., CARAMITU, A.-R., BORS, A.-M., VAIREANU, D.I., Mat. Plast., 54, no. 4, 2017, p. 720

17.RUS, T., BORS, A.M., CARAMITU, A.-R., LINGVAY, I., VAIREANU, D.I., Comparative studies on the thermal ageing of some painting materials, Mat. Plast., 55, no. 2, 2018,(in press)

18.LINGVAY, J., SZATMARI, I., PRIOTEASA, P., LINGVAY, M., TUDOSIE, L.M., Korroz. Figy., LIV (1), 2014, p. 15-21.

19.J AVIERRE, C., SARASA, J., CLAVERIA, I., FERNANDEZ, A., Mat. Plast., 52, no. 1, 2015, p. 116

20.CARAMITU, A., BUTOI, N., RUS, T., LUCHIAN, A.-M., MITREA, S., Mat. Plast., 54, no. 2, 2017, p. 331

21.LINGVAY, I., RUS, G., BURUNTEA, N., UPB Sci. Bull, Series B, 63 (3), 2001, pp. 29-36.

22.NAKAJ IMA-KAMBE, T., SHIGENO-AKUTSU, Y., NOMURA, N., ONUMA, F., NAKAHARA, T., Appl. Microbiol. Biotechnol., 51, 1999, pp. 134-140. 23.SIVAN, A., Current Opinion in Biotechnology, 22, 2011, pp. 422-426. 24.RAVIKUMAR, H.R., RAO, S.S., KARIGAR, C.S., Indian J. of Science and Technol, 5 (1), 2012, pp. 1977-1987.

25.RUS, T., RADU, E., LINGVAY, I., LINGVAY, M., CIOBOTEA-BARBU, O.C., CAMPUREANU, C., BENGA, F.-M., LAZAR, G.-C., VAIREANU, D.I., U.P.B. Sci. Bull., Series B, 79 (4), 2017, pp. 167-180.

26.PICÃ A., FICAl, A., Rev. Chim. (Bucharest), 67, no. 1, 2016, p. 34 27.RADU, E., LIPCINSKI, D., TANASE, N., LINGVAY, I., Electrotehnica, Electronica, Automatizari (EEA), 63 (3), 2015, pp. 68-74.

28.LINGVAY, I., RUS, G., STOIAN, F., LINGVAY, C., UPB Sci. Bull, Series B, 63 (3), 2001, pp. 263-270.

29.RADU E., MITREA S., PATROI D., VOINA A., MOSCALIUC H., LINGVAY I., 2016, DOI: 10.1109/DEMISEE.2016.7530483, IEEE Xplore, pp. 38-43. 30.PRIOTEASA, P., LINGVAY, M., SZATMARI, I., BURUNTEA, N., LINGVAY, I., Electrotehnica, Electronica, Automatizari (EEA), 62 (2), 2014, pp. 60-65. 
31.OLLERER, K., LINGVAY, I., Korroz. Figy., 45 (4), 2005, pp. 133-36. 32.LINGVAY, I., OLLERER K., LINGVAY C., HOMAN C., CIOGESCU 0., Rev. Chim. (Bucharest), 58, no. 7, 2007, p. 624

33.OPRINA, G., RUS, T., LINGVAY, D., CARAMITU, A., MITREA, S., Electrotehnica, Electronica, Automatica (EEA), 65 (1), 2017, pp. 81-87. 34.RADERMACHER, L., LIPCINSKI, D., BUTOI, N., LINGVAY, D., CARAMITU, A., MARIN, D., Electrotehnica, Electronica, Automatizari (EEA), 65 (2), 2017, pp. 140-146.

35.LINGVAY, I., GABOR, M., VOINITCHI, C.D., LINGVAY, C., Rev. Chim. (Bucharest), 57, no. 4, 2006, pp. 378

36.ISOC, D., IGNAT-COMAN, A., JOLDIS, A., AIP Conf. Proc. 1019, 2008, pp. 383-391.

37.LINGVAY, I., LINGVAY, C., HOMAN, C., CIOGESCU, O., Rev. Chim. (Bucharest), 57, no. 12, 2006, p. 1279

38.LINGVAY, I., BORS, A.-M., UNGUREANU, L.-C., STANOI, V., RUS, T., Studies on the behavior some paints in electro-insulating fluid based on vegetable esters, Rev. Chim. (Bucharest), 69, no. 5, 2018, (in press)

39.LINGVAY, I., UNGUREANU, L.-C., STANOI, V., RUS, T., BORS, A.-M., SZATMARI, I., OPRINA, G., Electrotehnica, Electronica, Automatica (EEA), 65 (4), 2017, pp. 117-122.

40.LINGVAY, I., Oprina, G., STANOI, V., PICA, A., UNGUREANU, L.-C., SERBAN, F., Rev. Chim. (Bucharest), 68, no. 11, 2017, p. 2551 41.DEGERATU, S., ROTARU, P., RIZESCU, S., DANOIU, S., BIZDOACA, N.G., ALBOTEANU, L.I., MANOLEA, H.O., J. Therm. Anal. Calorim. 119 (3), 2015, pp. 1679-1692.

42.LINGVAY, I., BUDRUGEAC, P., VOINA, A., CUCOS, A., MOSCALIUC, H., Rev. Chim. (Bucharest), 67, no. 11, 2016, p. 2202

43.DUMITRAN, L.M., CIURIUC, A., NOTINGHER, P.V., Advanced Topics in Electrical Engineering, Bucharest, 2013, May 23-25, pp. 1-6.

44.BUDRUGEAC, P., LINGVAY, I., PICA, A., SBARCEA, B.-G., Rev. Chim. (Bucharest), 68, no. 11, 2017, p. 2514

45.KAMISHIMA, S., IEEE Transactions on Dielectrics and Electrical Insulation, 19 (2), 2012, pp. 505-509.

46.VOINA, A., RADU, E., MITREA, S., OPRINA, G., LINGVAY, I., SERBAN, F., PICA, A., IEEE Xplore, 2016, pp. 44-47.

47.MCSHANE, C.P., RAPP, K.J ., CORKRAN, J.L., GAUGER, G.A., LUKSICH J., Proceedings of 2002 IEEE, 14th International Conference on Dielectric Liquids, ICDL, Graz (Austria), July 7-12, 2002, pp. 173-177. 48.LINGVAY, I., PATRU, I., UNGUREANU, L.C., STANOI, V., BORS, A.M., Electro-insulating paper degradation in various electro-insulating fluids, Rev. Chim. (Bucharest), 69, no. 1, 2018, p. 91
49.CENNAMO N., DE MARIA L., D'AGOSTINO G., ZENI L., PESAVENTO M., Sensors (Basel), 15 (4), 2015, pp. 8499-8511.

50.YUAN Z., CHEN M., LEI H., LIN, C., Power and Energy Engineering Conference (APPEEC), IEEE Xplore, 2010, pp. 1-3.

51.SABAU, J., OCKHUYZEN, R., Annual Report Conference on Electrical Insulation and Dielectric Phenomena, Victoria, BC, Canada, 1, October 2000, pp. 264-267.

52.CASSERLY E., RASCO, J.M., Stray gassing of refinery streams and transformer oil produced from them, 18th International Conference on Dielectric Liquids (ICDL), IEEE Xplore, 2014, pp. 1-4.

53.MARTIN, D., LELEKAKIS, N., WIJ AYA, J., DUVAL, M., SAHA, T., IEEE Transactions on Power Delivery, 29 (5), 2014, pp. 2369-2374.

54.FOFANA, I., SABAU, J., BUSSIERES, D., ROBERTSON, E.B., Proceedings of the IEEE International Conference on Dielectric Liquids (ICDL '08), 2008, pp. 1-4.

55.LINGVAY, I., STANOI, V., UNGUREANU, L.-C., OPRINA, G., LUCHIAN, A.-M., Thermochemical stability of some transformer oils -Flammable gas formation due to the thermal aging, Rev. Chim. (Bucharest), in press.

56.IVANKA, A.-H., 18th International Conference on Dielectric Liquids (ICDL), IEEE Xplore, 2014, pp. 1-3.

57.LINGVAY, I., STANOI, V., UNGUREANU, L.C., SERBAN, F., BORS, A.M., Electrotehnica, Electronica, Automatica (EEA), 65 (2), 2017, pg. 2330.

58.WEESMAA， ., STERNER, M., PAHLAVANPOUR, B., BERGELD, L., NUNES, J., 18th International Conference on Dielectric Liquids (ICDL), IEEE Xplore, 2014, pp.1-8.

59.*** https://docs.td.ppgpmc.com//download/593/593/ppg-aquacover200

60.***https://docs.td.ppgpmc.com//download/428/428/sigmaprime-200series

61. ${ }^{* * *}$ https://docs.td.ppgpmc.com//download/423/423/phenguard-930

62.***http://www.icpe-ca.ro/proiecte/proiecte-nationale/pn-2014/ uvpmee.pdf

63.*** EN 13599:2014 - Copper and copper alloys. Copper plate, sheet and strip for electrical purposes

64.*** ISO 4624:2016 - Paints and varnishes - Pull-off test for adhesion

Manuscript received: 11.10 .2017 